\title{
The Ethical Culmination of Aristotle's Metaphysics
}

\author{
CHRISTOPHER P. LONG \\ Richard Stockton College of New Jersey
}

\begin{abstract}
Aвsтract: This article suggests that Aristotle's Metaphysics culminates not in the purity of God's self-thinking, but rather in the contingent principles found in the Nicomachean Ethics. Drawing on such contemporary thinkers as Martin Heidegger, Hans-Georg Gadamer, Theodor Adorno, and Emmanuel Levinas, the article rethinks the relationship between ethics and ontology by reinvestigating the relationship between Aristotle's Metaphysics and Nicomachean Ethics. It is argued that the ontological conception of praxis developed in the middle books of the Metaphysics points already to the Nicomachean Ethics where a conception of knowledge-phronêsis-is developed that is capable of addressing the lacuna in the account of ontological knowledge offered in the Metaphysics.
\end{abstract}

The suggestion expressed in the title is rather bold and therefore easily misunderstood. It is not a philological claim asserted in the hope of establishing the genuine order and progression of Aristotle's Metaphysics, but a philosophical suggestion proposed as a possible reading of Aristotle informed by the contemporary concern to think through the relationship between ethics and ontology. The philosophical suggestion is that Aristotle's Metaphysics culminates not, as many have argued, ${ }^{1}$ in book XII and the clean purity of God's self-thinking, but rather in the far more ambiguous set of contingent principles developed in the Nicomachean Ethics. As a suggestion, this thesis does not aspire to objective verification, but is designed to open new avenues of investigation into the thinking of Aristotle. As philosophical, the thesis is not guided primarily by a concern to reconstruct the itinerary originally intended by Aristotle himself, but rather to locate resources in Aristotle's thinking that 
lend insight into the deep interconnection between ethics and ontology. ${ }^{2}$ However, to distinguish between philological claims and philosophical suggestions is not to endorse the legitimacy of any haphazard interpretation, for we have the inherited texts to hold us accountable. The method of genuine philosophical interpretation can never do more than trace the trajectory of the thinking expressed in the text which, as inherited, is necessarily refracted through the shattered lens of history.

The very idea that the Metaphysics should culminate in the Nicomachean Ethics emerges against the background of a number of developments in contemporary thinking that themselves have been deeply affected by and embedded in the politico-historical catastrophes of the twentieth century. First, Martin Heidegger's treatment of $\phi \rho o ́ \nu \eta \sigma \iota s$ in his lectures on Plato's Sophist and the more recent recognition by a number of scholars that Aristotle's Ethics had a profound influence on the project of fundamental ontology developed in Sein und Zeit already point to the possibility that the Nicomachean Ethics may have important ontological implications. ${ }^{3}$ Second, Hans-Georg Gadamer's retrieval of the hermeneutical significance of Aristotle's conception of $\phi \rho o ́ \nu \eta \sigma \iota s$ suggests that this ethical concept may be brought to bear on the ontological problem of the relationship between the universal and singular that haunts the middle books of Aristotle's Metaphysics. ${ }^{4}$ Third, Theodor Adorno's critique of all systems of identity implicitly corrodes the aura of authority of those interpretations that attempt to establish the onto-theology developed in Metaphysics book XII as the natural apex of Aristotle's thinking. ${ }^{5}$ Finally, Emmanuel Levinas has powerfully criticized the underlying tendency that often seems to animate such interpretations and indeed, Aristotle himself-namely, the desire to establish systematic order by subsuming all otherness under the authority of some absolute principle. ${ }^{6}$ Thus, although Levinas does not thematize it this way, his bold claim that metaphysics, which for him means ethics, is prior to ontology, may itself be understood as a sort of invitation to re-read the history of Western philosophy as something other than a history of totalizing ontologies, searching all the while for the trace of that ethical impulse which is eclipsed by the traditional preoccupation with systematic totality.

Taking up this invitation with regard to Aristotle entails rethinking the relationship between the middle books of the Metaphysics and the discussion of $\pi \rho \hat{a} \xi ı s$ and $\phi \rho o ́ \nu \eta \sigma ı s$ in the Nicomachean Ethics. To begin the process of such a rethinking, consider the following philosophical suggestion: The dynamic conception of oú $\sigma$ ía that emerges at the end of Metaphysics book IX as a response to the universal/singular aporia announced in book III requires a more sophisticated conception of knowledge 
than Aristotle has at his disposal in the middle books of the Metaphysics. Specifically, Aristotle's rigid adherence to the Socratic/Platonic assumption that all knowledge is universal leaves us, by the end of book IX, at a loss as to how knowledge of ov́rí $a$, there understood dynamically in terms of évé $\rho \gamma \in \iota \alpha$ or $\pi \rho \hat{a} \xi \iota s$, is at all possible. Metaphysics XIII.10, however, introduces, but leaves tantalizingly underdeveloped, a conception of knowledge that may be suitable to the dynamic conception of ov́ría developed in book IX. The thematization of ov́ría in terms of $\pi \rho \hat{a} \xi ı s$, when combined with this new conception of knowledge, leads us to the heart of the

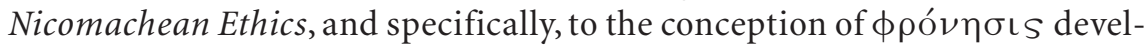
oped there.

In order to trace this possible development in Aristotle, it is necessary first to rehearse how the universal/singular aporia arises, at least in part, out of the conflicting ontological and epistemological demands Aristotle imposes on the principles of his ontology. When seen in relation to the universal/singular aporia the trajectory of the discussion of sensible ov' $\sigma i$ ía in the middle books comes more clearly into focus; for these difficult texts can be understood as an attempt to develop a dynamic conception of ov́ $\sigma i$ a capable of addressing the ontological side of the problem presented by the aporia. However, once this more dynamic conception of ov $\sigma i ́ a$ is developed, there remains a significant epistemological problem that does not find adequate redress in the middle books themselves. In order to locate a mode of knowledge appropriate for this more dynamic conception of oúría, it is necessary to look beyond the middle books first to Metaphysics XIII.10, and then, ultimately, to the heart of the Nicomachean Ethics and Aristotle's conception of $\phi \rho o ́ \nu \eta \sigma \iota s$.

\section{The Universal/Singular Aporia}

On the face of it, the universal/singular aporia seems to arise out of the conflict between two competing interests, the one ontological, the other epistemological. ${ }^{7}$ On the ontological level, the identity of each being must be established by its own peculiar principle in order to secure both its unicity and its distinction from other beings around it; for otherwise, as Aristotle says, "Socrates will be many things: Socrates himself, and a man, and an animal." ${ }^{\prime}$ On the epistemological level, however, if the principles of beings are singular and not universal, then there will be no possible knowledge of these beings, for knowledge is always universal. Thus, the aporia seems to arise out of Aristotle's attempt to establish an É ing, for if he gave up on the possibility that such beings are knowable, then the aporia would seem to dissolve. 
This appearance is in once sense correct, for Aristotle most often formulates the universal/singular aporia as a conflict between the demands of ontological identity and those of science. However, it is slightly more complicated than this appearance suggests, for even if, as Aristotle never would, we sequester the epistemological from the ontological concern, the ontological problem would still remain. This is clear from the formulation of another, related but somewhat distinct aporia, in which Aristotle asks whether there must exist a principle apart from the singular that accounts for its being. ${ }^{9}$ In this aporia concerning the separate existence of principles, Aristotle begins as would be expected by suggesting that knowledge requires that there is something that exists apart from the singulars, for if there were no such thing, the singulars would be sensible, but not know-

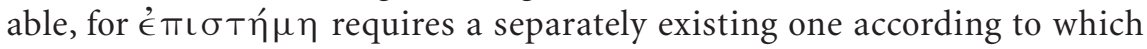
the many are determined. ${ }^{10}$ However, immediately thereafter, Aristotle leaves off the epistemological concern and suggests that even on what may be considered a purely ontological level, it seems that some ungenerated, stable principle separate from and capable of ontologically grounding the identity of the plurality of composite individuals must exist if there is to be anything at all. ${ }^{11}$ Thus, the aporia of separability, which itself is intimately intertwined with that of the universal and singular, emerges not only as a result of the conflict between epistemology and ontology, but also as a problem inherent to any attempt to account for the ontological identity of beings that must submit to the process of generation and decay, that is, of those beings with which Aristotle is primarily concerned in the middle books of the Metaphysics - finite, contingent composites of form and matter.

It is no surprise, therefore, that as the treatment of sensible ovoí $a$ in the middle books progresses, the specifically ontological problem of identity increasingly comes to occupy Aristotle's thinking and that, by book IX, something of a solution to the universal/singular aporia with respect to its ontological dimensions has been suggested. To trace this development as briefly as possible will be the purpose of the next section, however, it is necessary first to pause a moment to mention that even if a satisfactory passage has been found for the ontological problem, a full solution to the aporia cannot be achieved until the nature of the sort of knowledge suitable for this new ontological understanding is clarified. This, however, is precisely what the middle books lacks, what XIII.10 hints at, and what the notion of $\phi \rho o ́ \nu \eta \sigma \mathrm{s}$ in the Nicomachean Ethics supplies. To put the position suggested here boldly: Already in Aristotle, ethics is first philosophy. 


\section{The Dynamic Solution of the Middle Books}

To treat the difficult and controversial texts of the middle books in a brief, succinct and uncontroversial manner is nearly impossible. There have been numerous book length studies of the middle books, and there seems to be no end to the controversy over which sorts of beings actually count as primary ov́ríal and whether such beings are to be considered singular or in some sense universal. ${ }^{12}$ The concern in what follows is not to provide a unassailable argument for one position or another, but to adumbrate an interpretation of Aristotle's treatment of sensible oúría from the perspective of the question of ontological grounds raised by the two aporiae mentioned above.

That these two aporiae are at the core of the problems concerning the nature of sensible substance is indicated already by the criteria for being an oúría Aristotle sets forth in VII.3, when he argues that to be "separable" (Tò $\chi \omega \rho \iota \sigma \tau o ́ \nu)$ and a "this" ( $\tau o ́ \delta \in T \iota)$ are thought to belong most of all to an ov́ría. These two criteria seem to pull ov́ría in two directions at once; for, as separable, it must not only be capable of independent existence, but also of accounting for the being of a plurality of singulars; but as a "this," it must already be a concrete, demonstratively identifiable individual. Thus, one way to understand the trajectory of the middle books is to regard it as an attempt to find some passage between these two competing claims.

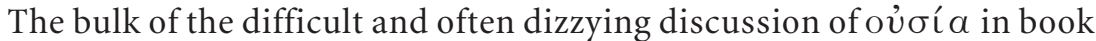
VII is animated by Aristotle's attempt and ultimate failure to negotiate such a safe passage. Once Aristotle recognizes that an account of oúría cannot be given exclusively in terms of form, as he does in the chapters of book VII leading up to and including $11,{ }^{13}$ and that whatever counts as ov $\sigma i ́ a$ cannot be universal because it must be a "this," as he does in chapter $13,{ }^{14}$ he alters his overall strategy of investigation. At the end of book VII, Aristotle shifts his perspective, no longer formulating the question of ov $\sigma$ í $a$ in its Socratic form ("What is X?"), but rather, asking the more penetrating and succinct question, "Why is this matter something," 15 that is, why is this matter an identifiable individual? This formulation opens up the possibility for Aristotle to think the identity of ov $\sigma i$ a in terms of the relationship between form and matter. The problem, however, remains as to how to understand the nature of this relationship and the terms involved; for as Aristotle beautifully argues in VII.17, the form does not seem to be an elemental part of the being as matter is, but "something different," which he

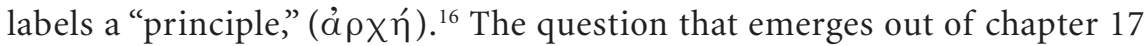


is precisely how to think the elemental together with this "something different," that is, how to think ov'oí $a$ as the identity of matter and form.

This question informs the peculiar double strategy of books VIII and IX in which Aristotle first revises and clarifies the criteria for oú $\sigma$ í $a$ introduced in VII.3 and second translates the reified notions of form and matter

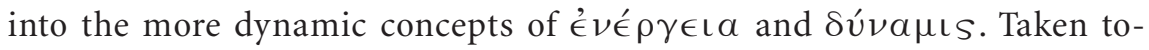
gether, these two strategic moves allow Aristotle both to circumvent the universal/singular and separability aporiae and to introduce a dynamic new conception of ontological identity.

In book VIII.1 Aristotle makes it clear that the terms “ $\tau o ́ \delta \in \tau \iota$ ” and " $\tau$ ò $\chi \omega \rho \iota \sigma \tau o ́ v "$ apply differently to matter, form and the composite: Matter he calls potentially, but not actually, a "Tó $\delta \in \tau \iota$ "; form, he says, is that which, "being a Tó $\delta \in T \mathrm{~L}$, is separable in $\lambda$ ó $\gamma$ os"; and the composite, which alone is generated and destroyed is "separate without qualification." 17 While the introduction of the equivocal meaning of these terms has been seen by some as an intellectual "cheat" or "sophistical dodge," 18 and although it causes considerable complications for those preoccupied with the so-called "population problem," ${ }^{19}$ it actually marks a profoundly important development in Aristotle's attempt to negotiate a safe passage between the universal/singular and separability aporiae. For once Aristotle suggests that form is only separable in notion, and not strictly speaking independent of the matter in which it inheres, the composite individual is given a sort of ontological priority and the entire problem of how a separately existing universal comes to be individuated dissolves. Once the separability criterion is revised in this way, that of the " $T$ ó $\delta \in \tau \iota$ " emerges as the decisive characteristic of où $\sigma$ í $a .^{20}$

Precisely what it means to be a "Tó $\delta \in ~ T \iota$ " has been the source of much debate for many years. ${ }^{21}$ However, Joseph Owens has powerfully argued that it emerges in the middle books of the Metaphysics as a technical term designed to designate that which, strictly speaking, is neither universal nor singular. ${ }^{22}$ For Owens, who defends the notion that form is primary oú $\sigma$ ía in Aristotle, the term refers to the substantial form, which, as the ground of the composite, is itself prior to the distinction between that which is universal and singular. Yet, as we have seen, the term itself applies most strictly to the separately existing composite, whereas the form is only called a " $T$ ó $\delta \epsilon$ $\mathrm{Tl}^{\prime}$ in the derivative sense that it is separable in $\lambda$ ó $\gamma \mathrm{os}$. This suggests the possibility that the term may be designed to point to the very enigmatic identity of the concrete composite individual, that being which presents itself as demonstrably present to, yet incompletely captured by concepts. As a "Tó $\delta \in \tau \iota$," the composite is no longer singular-inaccessible to knowledge and its concepts - but not yet universal-completely captured by the 
concept. Theodor Adorno has suggested that " $T o ́ \delta \epsilon \tau \mathrm{T}$ " is a sort of gesture to the facticity of the composite, "to that which cannot be dissolved in concepts and yet for which a conceptual name is sought." ${ }^{23}$ Indeed, the term, itself composed of a demonstrative and an indefinite, seems to point to the peculiar sort of ontological independence of the finite, sensible composite individual. Ernst Tugendhat has emphasized the rather remarkable way in which the term "Tó $\delta \in \tau \iota$ " gestures toward the twofold nature of the composite, which is at once determinate and indeterminate, concrete and yet elusive. ${ }^{24}$ Thus, although the "Tó $\delta \in T L$ " itself designates that which is individual, it points directly to the fact that this individual is always already encountered as composed of form and matter, two dimensions that themselves are neither universal nor singular, but function as the ontological grounds of the concrete composite individual itself.

If, however, this is the case, then some account must be given of the manner in which form and matter exist as a unity; that is, how they function as ontological grounds. This problem is addressed in the second move of Aristotle's double strategy, namely, the translation of the concepts of form and matter into the more dynamic notions of é $\nu$ é $\rho \gamma \in \iota \alpha$ and $\delta \dot{v} \nu \alpha \mu \iota s$, respectively. Aristotle suggests that once we understand form and matter in this way, it is possible to show precisely how they function together as the irreducible and equi-original grounds of the identity of the composite individual. ${ }^{25}$ This is, in fact, the main purpose of book IX, in which Aristotle

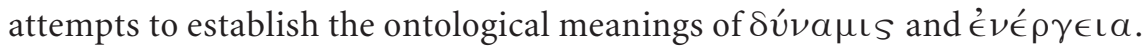

Aristotle begins book IX by rehearsing the meaning of $\delta u ́ \nu a \mu t s$ as it is most commonly used, namely, with regard to things in motion. The model of kí $\nu \eta \sigma \iota s$ (motion), however, turns out to be insufficient for the present purpose of developing a conception of being whereby évé $\rho \gamma \in \iota \alpha$ and

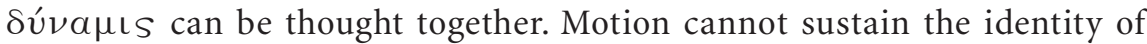

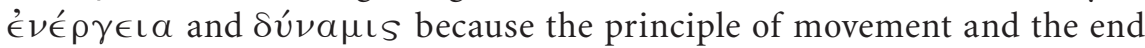
towards which the motion is directed remain outside of the motion itself. While a house is being built, for example, the material remains potentially, but not yet actually, a house; once it is completed, the house is actual, but no longer potential with respect to being a house. ${ }^{26}$ Aryeh Kosman puts this dynamic of Kí $\nu \eta \sigma \iota s$ memorably: "a motion is, so to speak, on a suicide mission. A motion is fully realizable only posthumously; while alive, it has not yet fully achieved its being." ${ }^{27}$ Because of this suicidal tendency and its inability to maintain itself in the realization of its end, motion cannot offer Aristotle the model by which to think ov́ría as the active identity of

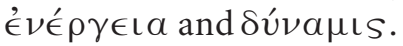

Over against the model of motion, however, Aristotle proposes an activity

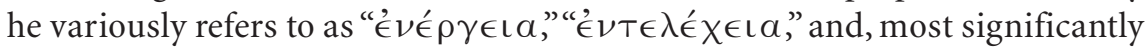


for the present purposes, " $\pi \rho \hat{\alpha} \xi ı$ s," that is capable of holding the tension between évé $\rho \gamma \in \iota \alpha$ and $\delta v ́ \nu \alpha \mu \iota s .{ }^{28}$ Unlike a motion, at each moment of its existence, an activity retains its potentiality and is fully realized at the same time-it exists for no purpose beyond this its activity; it is é $\nu T \in \lambda \eta ́ s-c o m-$ plete in itself. Here the relationship between évé $\rho \gamma \in \iota \alpha$ and $\delta v ́ \nu a \mu ı s$ is not only preserved, but also functions as the very condition for the possibility of the activity itself, for if potentiality is ultimately consumed, the activity will altogether cease. The examples Aristotle offers of such activities are heuristically helpful: While actively seeing, one does not lose the ability to see, nor while thinking, does one lose the ability to think, but rather, the ability is preserved in the very exercise of the activity itself. ${ }^{29}$ The ontological significance of this conception of activity cannot be overemphasized. Here Aristotle hits upon the sought after model according to which the identity of évé $\rho \gamma \in \iota a$

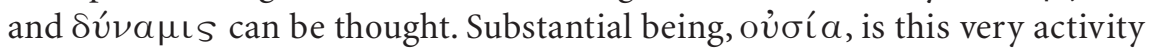
itself-an oúoía is what it is only so long as it actively embodies the rela-

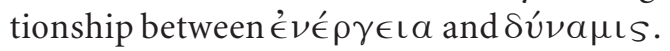

With this, a solution is discovered for the ontological problem uncovered in the face of the universal/singular and separability aporiae. Aristotle has focused his attention on the concrete individual, the Tó $\delta \in \tau l$, which, in its most strict sense, is the composite of form and matter. In the process, form has been reconceived; no longer understood as an universal

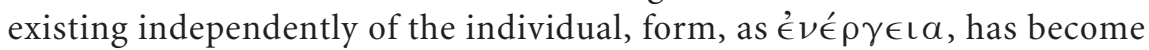
one of the two ontologically constitutive grounds of the individual, itself separable from the composite only in $\lambda$ ó $\gamma$ os. The other ground, however,

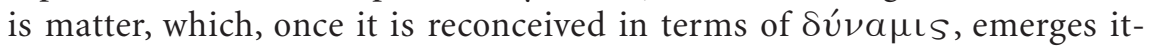
self as one of the fundamental grounds of the being of the individual; for the individual exists as itself only so long as the relationship between form-

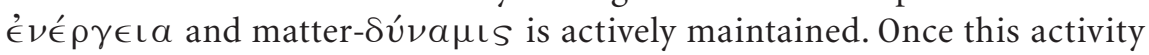
ceases, the being itself no longer is what it was-it loses its "what-it-wasto-be," its Tò Tí ク̉v $\in \hat{\imath} \nu a \iota$. Thus, by beginning with the concrete existence of the composite individual, Aristotle is able to think back to the grounds of its being, which themselves do not have any real existence independent of their relationship with one another.

By revising the criterion of separability, focusing his attention on the concrete individual, and reconceiving the notions of form and matter in terms of évé $\rho \gamma \epsilon \iota \alpha$ and $\delta v ́ \nu \alpha \mu \iota s$ respectively, Aristotle is able to address the ontological dimension of the separability and universal/singular aporiae. Although the composite requires the existence of something external to set it on its way to being, once this initial principle has been given, the composite is capable of taking it up into itself and making this principle its own. Indeed, Aristotle even says that such a being is not even potentially 
what it is until it has thus taken its own principle into itself. ${ }^{30}$ Once this is accomplished, its existence as an individual depends on its ability to actively maintain the relationship between évé $\rho \gamma \in \iota \alpha$ and $\delta v ́ \nu \alpha \mu \iota s$, which, as the ontological grounds of the individual, are prior to the distinction between universality and singularity.

However, if this story is satisfactory from a purely ontological perspective, it remains highly problematic from an epistemological point of view; for it seems to amount to a renunciation of the universal and thus of the

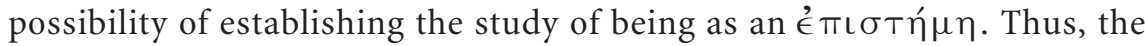
question emerges as to how knowledge of sensible ov́oía is possible if it is not something universal. ${ }^{31}$ Aristotle hints at a possible solution to this problem in Metaphysics XIII.10, when he reconsiders the assumption that generates the aporia itself. This assumption, inherited from Plato and Socrates and never explicitly questioned, is that because all knowledge is universal, if there is to be knowledge of ovं $\sigma$ í $a$, its principles too must be universal. ${ }^{32}$ Aristotle writes:

[T] he statement is on the one hand true and on the other not true.

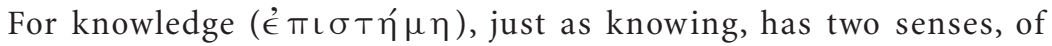
which one is in potentiality, the other in actuality ( $\left.\dot{E} \nu \in \rho \gamma \in \mathrm{I}^{\prime} \alpha\right)$. Potential knowledge, like matter, being universal and indefinite, is of the universal and indefinite, but actual knowledge, being definite, is of the definite, and being a Tó $\delta \epsilon \tau \iota$ is of the $\tau o ́ \delta \epsilon \tau \iota . .{ }^{33}$

Although this passage is somewhat truncated and Aristotle's discussion of this seemingly novel form of knowledge ends as suddenly as it appears, its basic structure seems clear enough and its significance is vital.

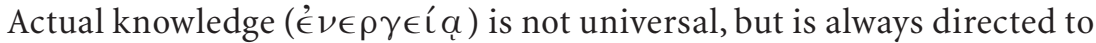
the Tó $\delta \in T \iota$ from which it is able, by a sort of abstraction, to construct the universal which may apply to a plurality of like beings. The term "may" here is important, for this sort of universality is always potential. It is ultimately dependent on the actual encounter with the definite Tó $\delta \epsilon \mathrm{Tl}$. Although it is certainly possible that with the term " $\tau o ́ \delta \epsilon \tau \iota$ " Aristotle means to refer to the form in distinction from matter, it is also reasonable to think that it is deployed in the more strict sense to refer to the concrete individual composite.$^{34}$ And while it is true that the distinction is drawn with reference to

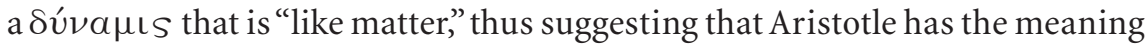
of '́ $\nu \in ́ \rho \gamma \in \iota a$ as form in mind, the key distinction in the text is the dichotomy between the indefinite (áopíoTos) and that which is definite

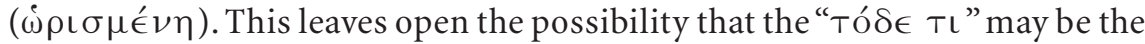
concrete composite individual whose ontological identity is itself a sort of É $\nu \in ́ \rho \gamma \in \iota \alpha$, or more strictly speaking, a $\pi \rho \hat{a} \xi \iota s$. More perspicuous than 
precisely what Aristotle means to point to with the term "Tó $\delta \in \tau L$," however, is the fact that he saw a need to revise his previous understanding of the nature of knowledge in order to accommodate his more dynamic conception of sensible ov́ría. ${ }^{35}$ The fact that Aristotle's discussion of this new conception of knowledge ends so abruptly invites an investigation into the possibility that there may be elsewhere in Aristotle another conception of knowledge suitable for this more dynamic conception of the ontological identity of sensible oủoía.

\section{Another Knowledge}

The first hint that the Nicomachean Ethics may be a possible place to look for this other conception of knowledge is found in Metaphysics IX.6 itself, where the model of activity is introduced. There are three aspects of this text that implicitly point in the direction of the Nicomachean Ethics. First, one of the words Aristotle employs to refer to the sort of activity developed there is " $\pi \rho \hat{a} \xi_{\mathrm{LS}}$," which is itself a main concern of the Ethics, and specifically of book VI, where it is juxtaposed with Toínoıs, or production. Of course, the mere appearance of this word does not of itself justify the appeal to the Ethics, for Aristotle uses the word elsewhere in a sense unrelated to the technical meaning it receives in either the Metaphysics or the Ethics. ${ }^{36} \mathrm{Sec}-$ ond, however, three of the five examples to which Aristotle appeals in the Metaphysics to clarify the meaning of this sort of $\pi \rho \hat{\alpha} \xi \iota s$ are taken from the practical sphere. Along with seeing and thinking which seem fundamentally theoretical, Aristotle lists living well $(\epsilon \hat{v} \zeta \hat{\eta} \nu)$, being happy $(\epsilon \hat{v} \delta \alpha \iota \mu o \nu \in \hat{\imath} \nu)$ and of particular significance, being practically wise $(\phi \rho о \nu \in \hat{\imath} \nu) .{ }^{37}$ Finally, the third hint that the Ethics may have some bearing on the text from Metaphysics IX.6 has to do with the nature of the distinction Aristotle attempts to establish there between $\kappa i ́ \nu \eta \sigma \iota s$ and $\pi \rho \hat{a} \xi \iota s$, for in NEVI, the distinction between $\pi$ oí $\eta \sigma \mathrm{\iota s}$ and $\pi \rho \hat{a} \xi \iota s$ is drawn along the same lines.

In the Metaphysics as in the Ethics, $\pi \rho \hat{a} \xi \iota s$ is distinguished from кí $\nu \eta \sigma \iota s$ and $\pi$ oí $\eta \sigma ı S$ respectively because unlike either, $\pi \rho \hat{a} \xi ı S$ has its principles of beginning and end in itself. Production, like motion, depends on something external for its principle-the producer and that which is produced remain, like the mover and that which is moved, separate, and the ends towards which they are directed distinct from the process by which these ends are achieved. ${ }^{38}$ Thus, despite Aristotle's frequent appeal to examples taken from the region of production, Toínoıs could no more hold together the

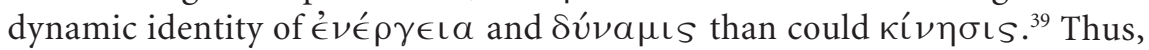
the vocabulary and examples deployed in the text from the Metaphysics not 
only anticipate the themes and vocabulary of the Nicomachean Ethics, but the distinction they are designed to establish is the same in both texts as well.

Obviously, these three peculiarities do not constitute incontrovertible evidence for the rather bold thesis that the Metaphysics culminates in the Ethics. Rather, they are traces, excesses left by the fecundity of Aristotle's thinking, which, if followed, invite us not only to rethink the manner in which Aristotle's ontology has been historically interpreted, but also to critically call into question the prejudice toward systematic completeness and absolute ultimates with which such interpretations have historically operated. Indeed, by attending to the ethical undertones of Aristotle's Metaphysics, a new, but nonetheless ancient, conception of ontology begins to emerge, one that is not obsessed with establishing the absolute order of things, but rather, is guided by and grounded in the direct encounter with the other.

The conception of knowledge introduced in Metaphysics XIII.10 already points in the direction of the other insofar as it is grounded in the actual encounter with that which is definite in itself. Yet it is not until the Ethics, when Aristotle turns his full attention to human $\pi \rho \hat{\alpha} \xi ı$ s and the knowledge peculiar to it, $\phi \rho o ́ \nu \eta \sigma \iota s$, that a full picture emerges of precisely how a knowledge grounded in such an encounter would look. To be sure, this is not the secure notion of knowledge Western philosophy has always dreamed of for its ontologies, for indeed, it is neither absolutely certain nor immune to error. However, in an era in which the dangers endemic to philosophy's myopic drive toward certainty have become devastatingly perspicuous, this other, less totalizing, more responsive form of knowledge emerges as genuine alternative to the epistemic model. ${ }^{40}$

\section{Ontological $\Phi \rho o ́ \nu \eta \sigma \iota s$}

The sort of knowledge introduced in Metaphysics XIII.10 resonates with the conception of $\phi \rho o ́ \nu \eta \sigma \iota s$ developed in the Nicomachean Ethics insofar as both are oriented toward the concrete individual. Just as the actual knowledge

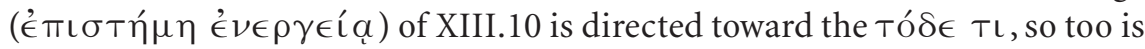

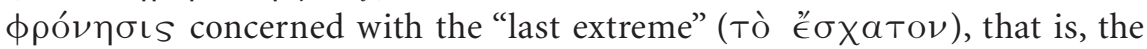

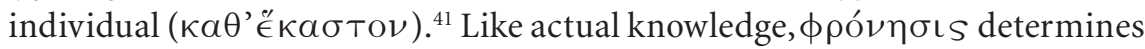
the universal from the direct encounter with the individual. ${ }^{42}$ Thus, the direction and nature of its operation seems to be the opposite of that of traditional $\dot{\epsilon} \pi \iota \sigma \tau \eta ́ \mu \eta$; for where $\dot{\epsilon} \pi \iota \sigma \eta \hat{\mu} \eta$ subsumes each individual it encounters under necessary universal principles it always already possesses ${ }^{43} \phi \rho o ́ \nu \eta \sigma \iota s$ remains constantly prepared to revise and rethink the universals with which it operates, recognizing that the universal itself is determined only in the direct encounter with the concrete individual. 
Here a deeper significance to Aristotle's suggestion in the Metaphysics that the universal is always potential but never actual begins to emerge; for in $\phi \rho o ́ \nu \eta \sigma \iota s$ the universal functions as a sort of prejudice that serves as a condition for the possibility of experience. ${ }^{44}$ Such prejudices emerge out of the nexus of our historical experiences and provide the context in which our encounters with other beings happen. Only when such prejudices become reified, blindly adhered to and severed from the direct encounter with the other do they become dangerous; that is, only when universals are understood to have an actual existence independent of the individuals themselves does the unhappy situation emerge whereby individuals are determined by some pre-conception, rather than recognized in concrete

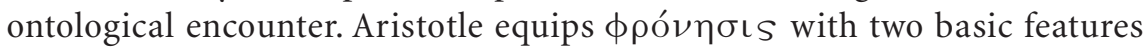
that allow it at once to minimize this sort of violent pre-judgment by which concepts are categorically imposed upon the individual, while maximizing the possibility of genuine ontological recognition by which concepts are conscientiously deployed.

These features of $\phi \rho o ́ \nu \eta \sigma \iota s$ all have to do with the peculiar sort of intuition it involves. Traditionally, intuition, or vov̂s, signifies the immediate apperception of the truth, which itself is necessary and eternal. In $\phi \rho o ́ \nu \eta \sigma \mathrm{s}$, the truth emerges in the encounter with the individual and can-

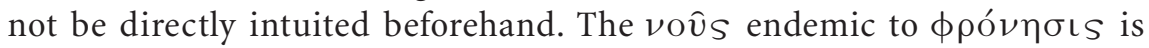
directed to that which presents itself in all its concrete contingency. Due to this contingency, the intuition of $\phi \rho o ́ \nu \eta \sigma \iota s$ must be supplemented by $\nu$ ov̂s. Such an intuition is therefore inherently mediated, discursive and deliberative. Further, it is closely linked with $\sigma u ́ v \in \sigma ı S$, which, although usually translated simply as "intelligence," takes on the far richer meaning of "conscientious apprehension" in relation to $\phi \rho o ́ \nu \eta \sigma \mathrm{s} .{ }^{45}$ Thus, the sort of intuition involved in $\phi \rho o ́ \nu \eta \sigma \iota s$, because it is deliberative and conscientious, respects the otherness of the individual even as it seeks to know this individual for what it is on its own terms, recognizing too that knowledge requires the deployment and thus imposition of concepts.

Thus, the intuition of $\phi \rho o ́ \nu \eta \sigma \iota s$ must be guided by $\sigma u ́ \nu \in \sigma \iota s$, "conscientious apprehension," which itself is intimately related to what Aristotle

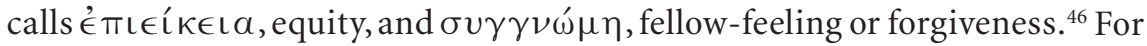

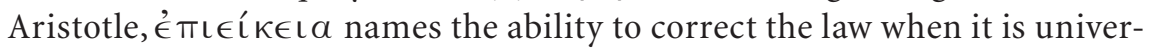
sally stated but does not fairly apply to the particular situation under consideration-equity is the ability to adapt the universal to the concrete contingencies of the situation at hand. To link this notion of equity to the operation of $\phi \rho o ́ \nu \eta \sigma \mathrm{s}$ is to equip phronetic judgment with an ability to dynamically respond to the individual qua individual and not as a mere instance of some abstract universal. It points to the fact that the universal 
itself is determined as universal only in the act of its application. ${ }^{47}$ This requires $\sigma v \gamma \gamma \nu \omega \dot{\mu} \mu \eta$, or forgiveness, precisely because the operation of $\phi \rho o ́ \nu \eta \sigma \iota s$ must deploy universals that inevitably impinge upon the unicity

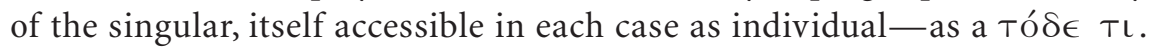
The recognition that the individual is at once irreducibly unique and yet always already determined by the concepts through which it is encountered enjoins the development of a conscientious conception of judgment that links forgiveness to equity.

The sheer complexity of the basic ontological encounter with the individual reinforces the notion that $\phi \rho o ́ \nu \eta \sigma \iota s$ is never immediate but is always mediated by a sort of deliberation that must consider not only past experience, but also the contingencies of the context in which the judgment is made and the propriety of the concepts through which the individual is encountered. Such deliberation is always rooted in the $\lambda$ ó yos that makes the encounter between beings possible and that indeed conditions their relation towards one another. ${ }^{48}$ This deliberative dimension of phronetic judgment recognizes that the judge as much as the being judged is determined in the act of judgment. It thus enjoins not only respect for the irreducible singularity of the individual, but also critical reflection upon the propriety of the principles with which it itself operates.

This self-reflective critical dimension of becomes particularly important when $\phi \rho o ́ \nu \eta \sigma \iota s$ is reappropriated as ontological knowledge, for once being is no longer understood either as some reified "thing" or as an equally static actus purus devoid of matter ${ }^{49}$ but rather as $\pi \rho \hat{a} \xi\llcorner S$, a more dynamic and indeed flexible form of knowledge is required. Static categories and eternal universals are incapable of capturing, once and for all, the being of the individual as $\pi \rho \hat{\alpha} \xi$ เS. Nor, indeed, ought ontological knowledge set as its goal this sort of conceptual entrapment in which beings are forced into categories imposed upon them from without - a goal that itself emerges out of an understanding of being determined by the models of production and motion. In the Metaphysics, however, Aristotle hints at something quite different, and $\phi \rho o ́ \nu \eta \sigma \iota s$ offers a way to think the sort of knowing proper to this different understanding of being. As $\pi \rho \hat{a} \xi \iota s$, being has become inherently unstable and destabilizing, in some sense it is novel at each new moment, and yet it is never purely anarchic, for it operates with a dynamic order of principles that vary according to the individual and the nexus of relations in which it is found. If there is to be some sort of knowledge of

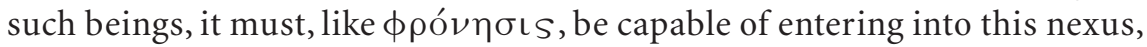
remaining constantly cognizant of its own determining involvement therein, loyal to the direct encounter with the concrete other being. For it is here, in the dynamic relation of this actual encounter, where the truth of 
being happens. Although Aristotle never explicitly formulates it this way, the features of deliberation, conscientious apprehension, equity and for-

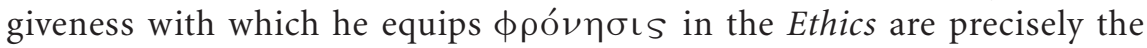
necessary features of an ontological knowledge that takes seriously the meaning of being as $\pi \rho \hat{\alpha} \xi$ เs. Thus, it may be suggested that even if it was never his intention, Aristotle has in fact already intimated how ontology is ethics and ethics ontology.

\section{Notes}

1. This tradition has been long established, finding its most explicit and powerful formulation in Aquinas's massive interpretation of the Metaphysics, see St. Thomas Aquinas, Commentary on Aristotle's Metaphysics, trans. John P. Rowan (Notre Dame, Ind.: Dumb Ox Books, 1995). It has been further affirmed by Hegel in his Vorlesungen über die Geschichte der Philosophie; see G. W. F. Hegel, Werke in Zwanzig Bänden, eds., Eva Moldenhauer and Karl Michel Markus (Frankfurt am Main: Suhrkamp Verlag, 1986): 19. More recently it has been endorsed by Joseph Owens; see Joseph Owens, The Doctrine of Being in the Aristotelian Metaphysics (Toronto: Pontifical Institute of Mediaeval Studies, 1978).

2. This essay anticipates the far more developed argument presented in Christpher P. Long, The Ethics of Ontology: Rethinking an Aristotelian Legacy (Albany: State University of New York, 2004).

3. See Martin Heidegger, Gesamtausgabe: Platon: Sophistes, ed. Friedrich-Wilhelm von Herrmann (Frankfurt am Main: Vittorio Klostermann, 1976); for the English see Martin Heidegger, Plato's Sophist, trans. Richard and André Schuwer Rojcewicz (Bloomington, Ind.: Indiana University Press, 1997). For a good discussion of the recent debate among Heidegger scholars on the precise nature of the impact of the Nicomachean Ethics on Sein und Zeit, see Robert Bernasconi, "Heidegger's Destruction of Phronesis," The Southern Journal of Philosophy 28, Supplement (1989): 127-147.

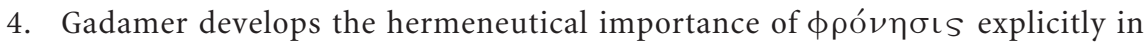
terms of what it has to offer our ability to understand the universal/singular relationship, see Hans-Georg Gadamer, Wahrheit Und Methode: Grundzüge Einer Philosophischen Hermeneutik (Tübingen: J. C. B. Mohr [Paul Siebeck], 1990), 317-330; Hans-Georg Gadamer, Truth and Method, trans. Joel Weinsheimer and Donald G. Marshall (New York: Continuum, 1994), 312-324. All future references to this text will be to the German followed by the English page numbers.

5. For Adorno's critique of identitarian thinking, see Theodor W. Adorno, Negative Dialektik (Frankfurt am Main: Suhrkamp Verlag, 1966); for the English, see Theodor W. Adorno, Negative Dialectics, trans. E. B. Ashton (New York: Continuum, 1994). All future references to this text will be to the German followed by the English page numbers. To be clear, Adorno himself does not explicitly critique specific interpretations of Aristotle, rather, he uncovers traditional 
philosophy's prejudice for systems of absolute order and the dangers endemic to such a prejudice.

6. Levinas's critique of Western ontology as a reduction of the Other to the Same is powerfully expressed in Emmanuel Levinas, Totality and Infinity, trans. Alphonso Lingis (Pittsburgh: Duquesne University Press, 1969). Aristotle's tendency to do this can be clearly seen in his treatment of God in Metaphysics XII.6-10. For a detailed analysis of this text, see Christopher P. Long, "Totalizing Identities: The Ambiguous Legacy of Aristotle and Hegel after Auschwitz," Philosophy and Social Criticism 29 (2003).

7. Following Joseph Owens's suggestion, the term "singular" here translates the Greek

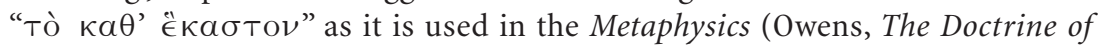
Being, 159n9). This is meant to carry over into the English Aristotle's insistence that "тоे $\kappa a \theta$ ' ёк $\alpha \sigma \tau о \nu$ " is unknowable. The term "individual" will not be employed until the technical meaning of " $\tau o ́ \delta \epsilon ~ T \mathrm{"} \mathrm{is} \mathrm{developed} \mathrm{in} \mathrm{Metaphysics}$ VIII.1. This terminological distinction is necessary if both the ontological solution to the universal/singular aporia and the epistemological problem to which this solution gives rise is to be properly understood. For a more detailed discussion of these distinctions, see Long, The Ethics of Ontology.

8. Aristotle, Aristotelis Metaphysica, ed. Werner Wilhelm Jaeger (Oxford: Oxford University Press, 1992), 1003a7-18. All references to the Metaphysics will follow this edition; translations are my own.

9. Aristotle, Metaphysics, 999a24-b24.

10. Aristotle, Metaphysics, 999a29-30. Edward Halper points this out very nicely when, in considering this aporia, he writes, "the principle needs to be apart because one is the principle of knowledge and only something that exists apart can be one" Edward Halper, One and Many in Aristotle's Metaphysics (Columbus: Ohio State University Press, 1989), 245.

11. Aristotle, Metaphysics, 999b13-20. Plato's influence, or at least the influence of Aristotle's understanding of Plato's thought, is palpable in this formulation of the problem. Although Aristotle finds Plato's alleged solution which appeals to separately existing forms in which individuals "participate" highly problematic (cf. 987b4-14 and 1078b8-1079b11), the problem of how to ontologically ground individuals remains.

12. There seems to be two major candidates for primacy: Form and the composite of form and matter. For a very good defense of forms, see Michael J. Loux, Primary Ousia: An Essay on Aristotle's Metaphysics $Z$ and H (Ithaca, N.Y.: Cornell University Press, 1991); for an equally good defense of the composite, see Mary Louise Gill, Aristotle on Substance: The Paradox of Unity (Princeton, N.J.: Princeton University Press, 1989). Of those who take primary oú $\sigma i ́ a$ to be form, some argue that the form is in some sense universal (see here Loux too), while others assert that the forms are singular, see, for example, Michael Frede and Günther Patzig, Aristoteles "Metaphysik Z" Einleitung, Text Und Übersetzung (München: C. H. Beck, 1988). There are, however, some who argue that the form is neither singular nor universal, but in some sense prior to the distinction 
between singularity and universality, see Owens, The Doctrine of Being, 386395. Finally, there are those who suggest that form is both universal and singular, see Halper, One and Many, 229-256. There Halper too has a good outline of the various possible positions on the issue.

13. See, Metaphysics, VII.11 1036b22-24, where Aristotle says "to reduce all things and to do away with matter is useless, for perhaps some things are this [form] in this [matter] or thus exist in this way." Obviously, I am passing quickly over a whole host of difficult issues concerning the interpretation of book VII that cannot be addressed here.

14. Here again I am swiftly moving over a very controversial issue. For a good defense of the position that Aristotle does not completely reject the possibility that oú $\sigma$ ía might be universal in some sense, see Loux, Primary Ousia, 197-235.

15. Aristotle, Metaphyscis, $1041 \mathrm{~b} 5$.

16. Ibid., 1041b12-32.

17. Ibid., $1042 \mathrm{a} 29$.

18. Donald Morrison, "Separation in Aristotle's Metaphysics," Oxford Studies in Ancient Philosophy 3 (1985): 125-157, 126. Far from being a cheat, this move indicates the extent of the flexibility of Aristotle's intellect; the sign of great genius is not the obdurate adherence to beliefs proven to be insufficient, but rather, the ability to revise one's position in the face of its limitations.

19. Furth calls the "population problem" the question concerning precisely which beings should count as oúríaı. Furth has recognized the importance of not becoming obsessed with this problem, which is, nonetheless, of significant importance, see, Montgomery Furth, Substance, Form and Psyche: an Aristotelian Metaphysics (Cambridge: Cambridge University Press, 1988), 54-58.

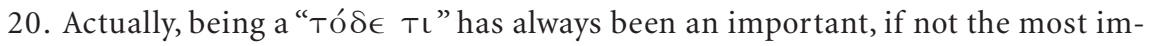
portant characteristic of Aristotle's understanding of oú $\sigma i ́ a$. It already appears in the Categories as a sign of something's being an ov́ría (3b10-23).

21. For a good discussion of the various interpretations of this term, see Owens, The Doctrine of Being, 386-395. Frede and Patzig take "Tó $\delta \epsilon$ " as a demonstrative pronoun that points to an instance of a class designated by " $\mathrm{Tl}$ " and translate the term "Dieses von der Art," or "this of the species" (Frede and Patzig, Aristoteles "Metaphysik Z” Text, 20). J. A. Smith's contention that any such translation/ interpretation is misguided insofar as it already assumes the universal/singular relationship is well founded. He suggests that the term refers to "anything which is both a this and a somewhat, the two characterizations being co-ordinate" ( $\mathrm{J}$. A. Smith, "Tode ti in Aristotle," Classical Philosophy: Collected Papers, ed. Terence Irwin [New York and London: Garland Publishing, Inc., 1995], 51). Aristotle

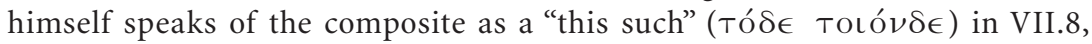
indicating there that the form is a "such" acting on a "this" and that the "entire

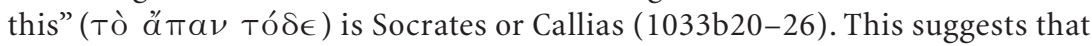
when "Tó $\delta \in \tau \iota$ " is used to refer to the concrete composite, it captures both sides of its rather ambiguous twofold nature: The fact that it is form and matter, activity and potency, determinate and indeterminate at once. 
22. Owens, The Doctrine of Being, 386-395.

23. Theodor W. Adorno, Metaphysics: Concept and Problems, trans. Edmund Jephcott (Stanford, Calif.: Stanford University Press, 2001), 35. Adorno seems to understand the " $\tau$ ó $\delta \in \tau \iota$ " as referring to the individual in its immediacy. However, it is far more likely that the expression gestures toward the always already mediated individual, that is, that finite being which, having already been made accessible through the deployment of the concept, retains its unique independence. To use Adorno's own vocabulary, the "Tó $\delta \epsilon \tau \iota$ ” in Aristotle gestures to the contingent object that will not go into its concept without remainder. See, Adorno, Negative Dialektik, 17/5.

24. Ernst Tugendhat, Ti Kata Tinos: Eine Untersuchung Zu Struktur Und Ursprung Aristotelischer Grundbegriffe (München: Verlag Karl Alber, 1958), 26.

25. Ute Guzzoni has powerfully argued that form and matter, É $\nu \in ́ \rho \gamma \in \iota \alpha$ and

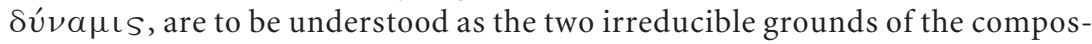
ite, see Ute Guzzoni, Grund Und Allgemeinheit: Untersuchung Zum Aristotelischen Verständnis Der Ontologischen Gründe (Meisenheim am Glan: Verlag Anton Hain, 1975), 166-185.

26. This is something of a simplification, for it is true that the matter of the house retains a certain potency-surely it can become something else. However, the goal toward which the Kí $\nu$ ¡ıs was directed has been achieved and therefore, the potency with respect to that goal has become actualized. For a detailed discussion of Aristotle's conception of kí $\nu \eta \sigma \iota s$ versus actuality, see Gill, Aristotle on Substance, 171-240.

27. L. A. Kosman, "The Activity of Being in Aristotle's Metaphysics," Unity and Identity in Aristotle's Metaphysics, ed. Theodore Scaltsas, David Charles, and Mary Louise Gill (New York: Oxford University Press, 1994), 203.

28. When referring to the technical meaning of activity, all three of these terms are interchangeable. However, to avoid confusion, I will refer to the activity by which

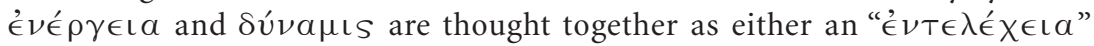
or a " $\pi \rho \hat{\alpha} \xi \iota s$ " respectively, depending on whether the relation to the end of the activity or the ethical dimension of the activity requires emphasizing. I will not use "É $\nu \in ́ \rho \gamma \in \iota \alpha$ " to refer to the activity itself so as not to confuse the '́ $\nu \in ́ \rho \gamma \in \mathrm{L} \alpha$ that names the formal side of the relation with the activity in which the relation is maintained.

29. Aryeh Kosman has correctly suggested that the distinction between first and second level realizations, in which, for example, a person possesses the ability to see but, because her/his eyes are closed, is not actively engaged in seeing at the moment (first level realization) and a person actively engaged in seeing (second level realization) is not really applicable to the sort of activity Aristotle

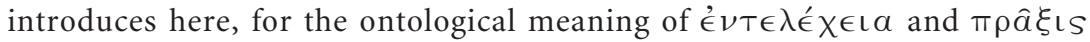
require that at each moment of its existence, ovं $\sigma i$ a must be in activity, that is,

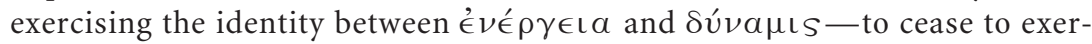
cise this activity is for an oúría to cease to be what it was, i.e. to die (Kosman, “The Activity of Being”, 206-209). 
30. Metaphysics, IX.7 1049a15-18.

31. Interestingly, this is as much a problem for those who take individual forms as oú $\sigma$ í $a$ as for those who take composites, for in both cases the individual seems to take precedence over the universal.

32. Metaphysics, XIII.100 1087a10-14.

33. Ibid., 1087a15-18.

34. Cf. Owens, The Doctrine of Being, $427 \mathrm{ff}$. For a more detailed defense of this point, see Long, The Ethics of Ontology.

35. Frede and Patzig recognize this passage as a fundamental revision of Aristotle's conception of knowledge which, for them, was developed because Aristotle had come to recognize form as individual (Frede and Patzig, Aristoteles "Metaphysik $Z$ ” Text, 56). Joseph Owens has suggested that although there are no direct references to the middle books, Aristotle must have had the doctrine developed there in mind when introducing this conception of knowledge (Owens, The Doctrine of Being, 427). While it is perhaps interesting to surmise whether Aristotle had this conception of knowledge in mind when he wrote what we have inherited as the middle books of the Metaphysics, precisely determining the chronological order of the texts is far less philosophically significant than the undeniable fact that such a conception of knowledge appears in Aristotle, whenever it was written. That it remains underdeveloped simply indicates the extent to which Aristotle's thinking points beyond itself and invites us to a deeper philosophical engagement with it.

36. See, for example, Parts of Animals, I.5, 645b15, where the $\pi \rho \hat{a} \xi$ เs of a being refers merely to its proper function and need not involve the technical meaning of action as complete in the sense of having its principle of beginning and end in itself.

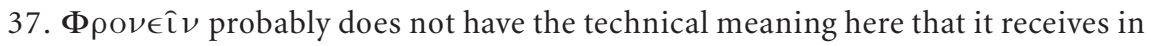
Nicomachean Ethics book VI. However, I have chosen to translate it as "to be practically wise" in order to emphasize its ethical undertones, which themselves

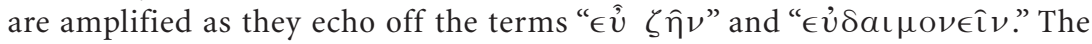
point is not to defend the thesis that $\phi \rho 0 \nu \in \hat{\imath} \nu$ here has the technical meaning $\phi \rho o ́ \nu \eta \sigma \iota s$ receives in the Ethics; rather, it is to accentuate a vocabulary that points us in the direction of the Ethics.

38. Compare Metaphysics IX.6, 1048b18-36 with Nicomachean Ethics VI.4, 1140a1-20.

39. If Heidegger was correct in calling Aristotle's Physics the "foundational book" of Western metaphysics because it understood being primarily in terms of production (see, Heidegger, Martin, Gesamtausgabe: Wegmarken, ed. Friedrich-Wilhelm von Herrmann [Frankfurt am Main: Vittorio Klostermann, 1976], 242.), then already in Aristotle, this metaphysics of "productive comportment" was being undermined in the Metaphysics itself when the model of motion was deemed incapable of accounting for the dynamic identity of

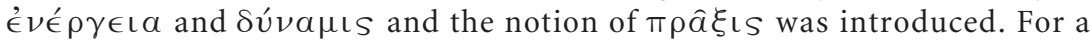
discussion of the notion of "productive comportment" and the Greeks, see 
Martin Heidegger, The Basic Problems of Phenomenology, trans. Albert Hofstadter (Bloomington, Ind.: Indiana University Press, 1988), 99-121. Reiner Schürmann has suggested that once Aristotle draws the distinction between Toínoıs and $\pi \rho \hat{a} \xi ı s$ in the Nicomachean Ethics, "then the element of domination is no longer decisive for praxis, and the end of an action becomes immanent to that action" (Reiner Schürmann, Heidegger, On Being and Acting: From Principles to Anarchy, trans. Christine-Marie Gros and Reiner Schürmann [Bloomington, Ind.: Indiana University Press, 1987], 103). However, the distinction between kí $\nu \sigma \mathrm{\iota s}$ and $\pi \rho \hat{a} \xi$ เS in the Metaphysics already indicates the waning efficacy of the dimension of domination and with it the preeminence of production in the face of the notion of ontological action.

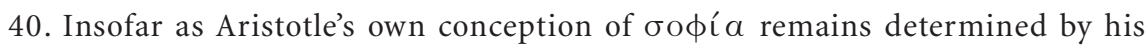

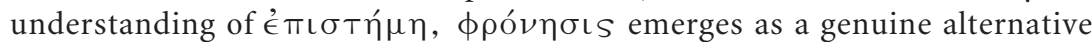
to philosophy itself. In the Nicomachean Ethics, Aristotle calls ooфía,

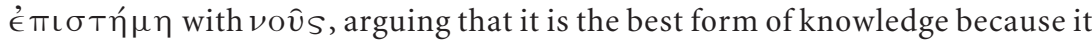
is universal, eternal and incapable of being wrong (cf. 1141a18-20 and 1141b23 ). This ideology of absolute truth and eternal certainty has revealed itself as misguided and extremely dangerous. For a detailed discussion of the ideology of absolute truth as it relates to Aristotle's conceptions of $\sigma o \phi i ́ a$ and $\phi \rho o ́ \nu \eta \sigma \iota s$, see Christopher P. Long, “The Ontological Reappropriation of Phronesis," Continental Philosophy Review 35, 1 (2002): 35-60.

41. Aristotle, Aristotelis Ethica Nicomachea, ed. I. Bywater (Oxford: Oxford University Press, 1894), VI.8 1141b14-16; VI.9 1142a23-25 and VI.12 1143a27-35.

42. Ibid., 1143 b5.

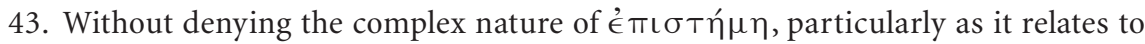
$\nu o \hat{v} s$ and $\epsilon \operatorname{Ta\gamma } \omega \gamma \hat{\eta}$, it is possible to characterize the operation of demonstra-

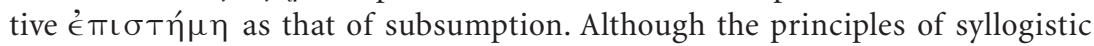
demonstration are obtained from the concrete experience with individuals by

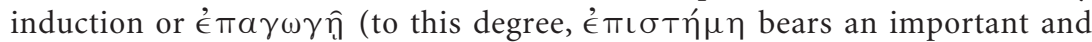
often overlooked affinity to $\phi \rho o ́ \nu \eta \sigma \iota s)$, once the principles are obtained, epistemic demonstrations determine individuals according to the universal principles they already possess, see Nicomachean Ethics, Z.3, 1139b26-31. In the Posterior Analytics, Aristotle claims that there can be no unqualified demonstration of those beings that are destructible, for the universal principle may apply to them at a certain moment, but not at another time. In such a case, the syllogistic demonstration would not be universally valid, for the middle term would be destructible, see Posterior Analytics, A.8, 75b23-36. Thus, the sort of universality

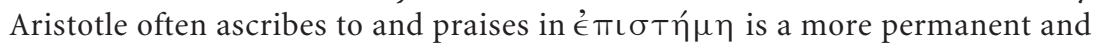
stable universality than the one developed in Metaphysics XIII.10, which ultimately depends on the actual encounter with the individual.

44. Gadamer has introduced the notion that prejudice, or "Vorurteil," which literally translated means "pre-judgment," serves as a precondition for all understanding; for we always bring prejudices, whether recognized or not, whether negative or not, to our encounters with other beings (Gadamer, Wahrheit 
und Methode, 250-ff./235-ff.) For a good analysis of this dimension of Gadamer's thinking, see Richard J. Bernstein, "From Hermeneutics to Praxis," Review of Metaphysics 35 (1982): 823-845, esp. 826-828.

45. For a defense of the admittedly bold translation of $\sigma u ́ \nu \in \sigma \iota \mathrm{S}$ as "conscientious apprehension," see Long, "Ontological Reappropriation of Phronesis," 45-46.

46. Nicomachean Ethics, 1143a1-1143b14. For a discussion of the meaning of $\sigma u ́ \nu \in \sigma \iota s$ in this context, see Gadamer, Wahrheit und Methode, 328-329, 322323.

47. Gadamer emphasizes the importance of application or "Anwendung" in which the universal and individual are co-determined (Gadamer, Wahrheit und Methode, 312 ff., 307 ff.).

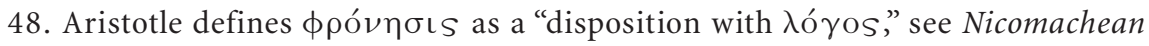
Ethics VI.5, 1140b4-6. Hannah Arendt has pointed to the important revelatory function of speech in the Human Condition, suggesting that in speech and action, human beings reveal their unique distinction to one another. See, Hannah Arendt, The Human Condition (Chicago: University of Chicago Press, 1958), 175-181. Martin Buber, however, has made the speaking of the genuine word a matter of prime ontological significance, suggesting that it is only in speaking the genuine word of relation "I-Thou" that beings participate in the realm of true reality: "All real living is meeting." See, Martin Buber, I and Thou, Walter Kaufmann (New York: Scribner's Books, 1970), 15. However, Buber takes the extra, rather extraordinary but nonetheless vital, step of expanding the boundaries of speech to include non-conscious beings - see the example Buber brings of his genuine encounter with a tree (10-12). If $\phi \rho o ́ \nu \eta \sigma \mathrm{s}$ is expanded in this way, it begins to look like a very powerful phenomenological faculty.

49. Adorno has correctly pointed out that no matter how dynamically expressed, once a system establishes closure by appealing to some ultimate principle, as Aristotle does when he appeals to the pure act of God's being, it immediately becomes static (Adorno, Negative Dialektik, 37/27, 201/201, 325/332). For a discussion of the totalizing dimensions of such static thinking, see Long, "Totalizing Identities." 